Testing and Validating Customer Relationship Management Implementation Constructs in Egyptian

Tourism Organizations ${ }^{1}$

Riyad Eid ${ }^{2}$

United Arab Emirates University - UAE

Hatem El-Gohary

Birmingham City University Business School, UK

Cairo University Business School, Egypt

Authors:

Corresponding author:-

Dr Hatem El-Gohary

Reader in Marketing

Birmingham City University Business School, UK

Editor in Chief: International Journal of Online Marketing (IJOM)

Address:

Birmingham City University, City North Campus, Birmingham, West Midlands, B42 2SU, UK

Phone: $+44(0) 7525721537$

E-mail: hatem.elgohary@bcu.ac.uk and elgohary70@yahoo.com

Dr Riyad Eid

Associate Professor of Marketing

United Arab Emirates University

Editor in Chief: International Journal of Customer Relationship Marketing and

Management

Address:

United Arab Emirates University

P.O. Box 15551, Al-Ain, United Arab Emirates

Phone: +97137133380

E-mail: $\underline{\text { riyad.aly@uaeu.ac.ae }}$

\footnotetext{
${ }^{1}$ This paper has been accepted by Journal of Travel and Tourism Marketing. Proof is attached in the appendices.

${ }^{2}$ Both authors contributed equally to this paper and authors' names are displayed in alphabetical order by surnames.
} 


\title{
Testing and Validating Customer Relationship Management Implementation Constructs in Egyptian Tourism Organizations
}

\begin{abstract}
$\underline{\text { Abstract }}$
To date, Critical Success Factors (CSFs) for implementing Customer Relationship Management (CRM) have not been systematically investigated. Existing studies have derived their CSFs from different perspectives. However, it lacks scientifically developed and tested constructs that represent an integrative CRM philosophy. Through a detailed analysis of the literature as well as adding new factors, this research identifies 8 constructs for integrated CRM implementation in developing economies. The proposed CSFs are tested and validated through a sample of 162 Egyptian tourism organizations that utilize CRM systems, using Amos 19. The overall results from the empirical assessment were positive, reflecting the appropriateness of the proposed CSFs. This study is one of very few studies to provide an integrative perspective of CSFs for implementing CRM in the tourism sector and developing economies and add to the extremely limited number of empirical studies that has been conducted to investigate CRM implementation in developing countries.
\end{abstract}

\section{Keywords:}

Customer Relationship Management, CRM, Critical Success Factors, Empirical Study, Questionnaire, Egypt, Services Marketing, SEM, Developing Economies

\section{INTRODUCTION}

Customer Relationship Management (CRM) has gained a lot of interest from researchers, policy makers and practitioners during the last two decades. Most researchers and practitioners consider CRM as a very important tool to increase any organization ability to gain, retain and satisfy customers both efficiently and effectively through creating and sustaining good long-lasting relationships with customers (El-Gohary, 2011 and El-Gohary, et. al 2013). As a result, CRM is currently considered as one of the most important means of establishing competitive advantage. 
Although CRM is highly related to Relationship Marketing (RM), it is also highly rooted and related to the use of technology to manage the company relationship with its customers. This is noticeable in the different definitions used to define CRM. For example, Kincaid (2003) define CRM as "the strategic use of information, process, technology, and people to manage the customer's relationship across the whole customer life cycle (Kincaid, 2003; p: 41). Moreover, Information Technology (IT) and Information Systems (IS) can be used to support and integrate CRM processes to satisfy customer needs (Law, 2009). Accordingly, IT and information systems play a key role in the development of efficient and effective CRM (Kincaid, 2003).

Meanwhile, the rapid changing business environment, the rise of competition among companies, shrinkage of markets, and diffusion of the IT through organizations and their marketing channels have put high pressure on businesses all over the world to continually review and amend their traditional marketing strategies (Eid, 2007). However, due to the continuance and rapid improvements in IT and computer technology, it is essential for any organization to have a well-designed and managed information system, which can help the organization in improving its performance, undertake better decision, improve the decision making processes, and achieve a competitive advantage. Thus many organizations have moved from standalone business information system applications to integrated and flexible enterprisewide systems such as CRM and Enterprise Resource Planning (ERP) systems. In fact managers cannot afford to avoid thinking about the impact of CRM on their businesses. At the very least, they need to understand the opportunities that CRM can provide to them and recognize how their companies may be vulnerable if rivals seize such opportunities first.

However, successful CRM implementation is a complex and difficult process. It causes vast change within the organization that needs to be managed carefully to get the full advantage of CRM software. It is really a mistake to view CRM project implementation as only an IT project (Greenberg, 2010; Kimiloglu and Zarali, 2009; Lukkari, 2011; Johnson, 2004; McKenzie, 2001; Davenport and Short, 1990; Porter, 
1987; Chen and Popovich, 2003; Ranjan and Bhatnagar, 2011). CRM has become one of the critical driving forces for business success. Abbott et al., (2001), Avlonitis and Panagopoulos (2005), Bhaskar (2004), Chan (2005), Chen and Popovich, 2003, Eid (2007), Hart et al., (2004), Karakostasa et al. (2004), and Zablah et al. (2004) conducted studies to understand the different factors that are needed to enhance CRM implementation. However, as will be argued within this research, these studies did not provide a systematic scale development, content validity, and/or empirical validation for such factors. Hence, the generalization of the results of such studies will be very difficult.

Meanwhile, as tourism is one of the most important sources for the Egyptian economy, it is important to find new ways of helping Egyptian organizations working in tourism sectors in conducting its business in an effective and efficient way. To achieve this objective, and as a step toward a theory building in the field of CRM, this paper aims to follow Schendel and Hofer (1979) robust approach to test and validate CRM implementation constructs in developing economies (Egypt). The validation will be conducted in five phases, namely: (1) exploration, (2) construct development, (3) hypothesis generations, (4) hypothesis testing for internal validity, and (5) testing for external validity. Such validation is going to build on the current body of knowledge in the field of CRM.

\subsection{CRM and Egyptian tourism organizations:}

Egyptian organizations have more than seven thousand years of recorded history (Fakhry, 2006). Ancient Egypt was among the earliest civilizations that discovered the value of work and the real meaning of entrepreneurship (El-Gohary, 2009). That can be seen obviously on the drawings on Egyptian temples all over the country and old papyrus papers (El-Gohary, 2009 and Fakhry, 2006). Furthermore, tourism is expected to be the engine of economic growth in Egypt over the next several decades and is expected to create the jobs needed by its ever growing population (Abdelhamed and Elhousaney, 2009). Moreover, with no doubt, Egypt is one of the leading tourist attractions among countries of the world and is highly considered as a unique case that cannot be matched. As a result, tourism does play a very important and major role in the Egyptian economy today and is recognized as 
one of the main sources of economic development and employment growth in Egypt. According to the Egyptian Ministry of Tourism (2011), the number of tourists' visited Egypt in 2010 was 14.7 million tourist compared with only 12.5 million tourist in 2009 with an increase of 2.2 million tourist $(17.5 \%)$. As a result the total number of tourist nights increased from 32.6 million nights in 2002 to 126.5 million nights in 2009 and 147.4 million nights in 2010 generating an income of 12.53 billion American Dollars in 2010 with an increase of $16.5 \%$ than the revenues in 2009.

As a result of the growing tourism activities in Egypt, the devoted efforts of the Egyptian government to promote Egyptian tourism, the big investments that the Egyptian government injected in all tourism sectors and massive developments in tourism infrastructure, the number of Egyptian organizations working in tourism sectors increased rapidly and dramatically from only 331 company in 1982 to 1083 company in 2003 and then to 1844 company in 2010 in addition to 902 foreign tourism organizations(El-Gohary, 2012). When looking to the regional distribution of Egyptian organizations' working in tourism, although providing the regional distribution figures for these organizations will assure representativeness of the sample, this is not possible due to the lack of data regarding the actual regional distribution of Egyptian tourism organizations. The authors tried all the possible means to reach such data when conducting the research without any success. However, it is commonly accepted (by Egyptian tourism researchers and experts El-Gohary, 2012) that Egyptian tourism companies are well distributed all over the country with the majority of them based in Cairo.

Meanwhile, CRM can be viewed as a new philosophy and a modern business practice involved with gaining, retaining and satisfying customers both efficiently and effectively through creating and sustaining good long-lasting relationships with them. By reviewing the relevant literature it is noticed that definitions of CRM vary according to each author's point of view, background and specialization. For that, while Parvatiyar and Sheth (2001), defines it as: "a comprehensive strategy and process of acquiring, retaining, and partnering with selective customers to create superior value for the company and the customer; it involves the integration of marketing, sales, customer service, and the supply-chain functions of the organization to achieve 
greater efficiencies and effectiveness in delivering customer value" (Parvatiyar and Sheth, 2001; p: 5), Kincaid (2003) define CRM as "the strategic use of information, process, technology, and people to manage the customer's relationship across the whole customer life cycle (Kincaid, 2003; p: 41). Also according to Injazz and Karen, (2004), CRM is: "a coherent and complete set of processes and technologies for managing relationships with current and potential customers and associates of the company, using the marketing, sales and service departments, regardless of the channel of communications" (Injazz and Karen, 2004; p: 673).

Regardless of all the known definitions of CRM, Law (2009) argues that technology is a very important element in defining CRM by both practitioners and academics. It is also accepted that the revolution in IT and communications changed the way people conduct business today. In recent years, increasing numbers of businesses have been using the Internet and such technologies in their marketing efforts, giving the chance for CRM (as a new marketing phenomenon and philosophy) to grow in a very dramatic and dynamic way. Accordingly, IT and information systems do play a key role in the development of CRM (Kincaid, 2003). According to Ngai (2005), they can not only be used to automate and enable some or all CRM processes but also appropriate CRM strategies can be adopted through the assistance of technology, which can manage the data required to understand customers. Moreover, the use of IT and IS can enable the collection of the necessary data to determine the economics of customer acquisition, retention, and life-time value (Ngai, 2005; p: 585).

\subsection{Research Problem and Questions:}

The fundamental problem motivating this study is the need to know and understand the different critical success factors (CSFs) constructs of CRM implementation in developing economies as well as the need to develop items of measuring for these scales. Meanwhile, as the theory in the field of CRM is still in its infancy stage and yet not well established there is a need for having more wellestablished studies that can be considered as a step toward a theory building in the field. To conduct these well-established studies, researchers within the field need to acquire a good understanding about the different CSFs of CRM implementation. 
Accordingly, the main question that the study attempts to answer is: what are the different critical success factors (CSFs) constructs of CRM implementation in developing economies?

\subsection{Research Objectives:}

The main purpose of this research is to contribute to the first three phases of CRM theory building. In particular, the major objectives of this research are to:-

1. Identify CSFs constructs of CRM implementation in developing economies and develop items of measuring these scales,

2. Empirically validate the scales, and

3. Carry out an initial investigation of the relationships, if any, among the CRM constructs.

The reminder of this paper is organised as follow. First, a review of relevant CRM literature is presented. This is followed by identification of CRM constructs and development of related scales. Empirical validation of the constructs is presented next. Based on of the exploratory analysis of the statistical relationships among various CRM constructs, managerial implications are offered. The paper concludes with recommendations for future extension of this research.

\section{LITERATURE REVIEW}

Regardless of the massive interest gained by researchers towards CRM, the review of the literature showed limited interest in investigating the different factors affecting critical success factors (CSFs) constructs of CRM implementation in developing economies. In contrast, a broad range of factors that can influence the success of CRM implementation in developed economies has been mentioned in the literature. For example, Harrigan (2011), Kimiloglu and Zarali (2009) and Cho et al. (2002) noted that an effective CRM strategy has a critical role to play in the implementation of CRM strategies if the appropriate training was provided. However top management team's support is one of the keys to integrate the legacy systems with CRM plan (Pushmann and Alt, 2001). Meanwhile, Bose (2002) agreed that 
correct planning for training sessions, management support and staff awareness programs are important for successful CRM implementation.

Furthermore, the literature shows a considerable interest and discussions on the importance of customer dimensions such as: customer acceptance, the use of the customer feedback as an enabler, not the driver of CRM implementation (Eid, 2007; Hart et al., 2004; Jutla et al., 2001). Al-Mashari and Zairi (2000) also argue that benchmarking is an important factor for the effective implementation of the CRM. Within the same line, Ranjan and Bhatnagar, 2011 and Umashankar (2001) showed the importance of Data Mining as a necessary element to fulfil obligations in CRMbased marketing.

Meanwhile, Dubrovski (2001) and Harrigan (2011) indicated that successful CRM implementation requires an enterprise-wide integration of processes and a change in management focus and business performance metrics. In support with that, Chan (2005) agreed that an integrated business model that ties together business organizations, processes, information and technologies along the entire value chain is critical to the success of CRM strategies. However, the literature review undertaken revealed a lack of research with regard to some critical factors of CRM implementation (e.g. Software Selection, benchmarking, and data mining), and this could be due to the fact that these factors are related to any information system project, not particularly to CRM project implementation only. However, this paper proposes a holistic framework for CRM project implementation based on an extensive review of the factors and essential elements that contribute to success of CRM project implementation.

\subsection{Research Constructs:}

This section deals with defining constructs identified from the literature and generates items that represent manifestation of these constructs. Constructs are latent variable which cannot be measured directly (Ahire et al., 1996). For example customization is a construct that cannot be measured directly. However, when customization is adopted, CRM can be used to design and customize products/services. Thus, using CRM to design and customize products/services can 
be one of the manifestations of customization efforts (Ahire et al., 1996). For a field study, each manifestation is measured with an item in a scale. However, following Ahire et al., (1996) approach, when the items in a scale sufficiently span the scope of the construct, the scale is said to have content validity (Ahire et al., 1996). To assure content validity of the constructs of this research, both the constructs and representative items were identified through a thorough review of the literature.

\subsubsection{Top Management Support:}

Successful implementation of CRM has been found to occur when top management exhibits commitment to change as well as commitment to CRM implementation effort. This can be defined as the widespread sponsorship of CRM. However, support is evidenced through commitment of resources (such as time, efforts and money) for educating and training employees, assignment of key employees throughout the innovation process, and money to purchase the technology and support the multiyear implementation effort (Eid, 2007; Heygate, 1999; Ocker and Mudambi, 2003).

There are a number of studies that had investigated top management support as one of the factors that affect the adoption of new technologies. From these studies: Al-Qirim (2006), Al-Qirim (2007), Damaskopoulos and Evgeniou (2003), Lal (2005), Yu (2006), Fillis, et al (2004), Mirchandani and Motwani (2001), Lertwongsatien and Wongpinunwatana (2003), Seyal and Abd Rahman (2003), Tsao, Lin, and Lin (2004), Stylianou et al (2003) and Looi (2004). Moreover, some studies had shown that new information technology systems will only succeed if there is support from senior management and this remains true in smaller organizations (Daniel and Myers, 2000), where the tendency to adopt electronic commercial activities will be strongly associated with the importance placed on an E-Business strategy within the firm (Stokes, 2000; Magnusson, 2001).

According to Chen and Popovich (2003), management must show high level of commitment to an ongoing company-wide education and training program. Additionally, management must ensure that job evaluations, compensation programs, and reward systems are modified on a basis that facilitate and reward customer 
orientation activities and behaviors. After all, how people are measured will determine their behaviour. Accordingly, for the purpose of conducting this research, the researchers developed the following four-item scale to represent top management commitment to CRM project:

1. Allocation of adequate resources to CRM efforts,

2. Relative importance given by the top management to CRM,

3. Relative importance given by the top management to CRM as a strategic issue, and

4. Performance measure based on CRM implementation.

\subsubsection{Developing a Clear CRM Strategy:}

Viewing CRM as a piece of software is the biggest mistake that is made by most failed CRM projects. CRM is a business strategy supported by software not the other way around. Therefore, an effective CRM strategy is required for a successful CRM implementation. A clear strategy that focuses on the goals of maintaining customer loyalty and using complaint-handling data to solve the different problems and address issues raised by customers is required for successful CRM implementation (Cho et al., 2002; Ranjan and Bhatnagar, 2011). To differentiate itself in the market, an organization has to create a working model that considers schedule, budget and what it hopes from CRM. The organization should think in terms of processes, not systems. A deep analysis of how ready the organization is to undertake a big initiative such as CRM has to be made. To minimize the risk of failure, this deep analysis will show the amount of change required to start implementing CRM. It gives a big picture of the overall organizational readiness. CRM initiatives require vision and each and every employee within the organization must understand the purpose and changes that CRM will bring (Umashankar, 2001).

Setting accurate expectations concerning the CRM system contributes to greater system usage. Indeed, in situations where employees know exactly what to expect from system implementation, the process of system acceptance will be smoother and more effective (Morgan and Inks, 2001). Organizations with successful CRM implementations did not view CRM as an IT project related to a specific department. The objectives and how the CRM solution supports them must be made 
clear to all areas of the organization. There has to be a clear understanding that CRM software is an enabler that will bring powerful automation to manual processes. Hence, the researchers measured the construct of clear CRM strategy with the following four-item scale:

1. Clear project vision/Scope,

2. Change required to start with CRM,

3. Clarity of CRM goals, and

4. Developing a Clear CRM Strategy.

\subsubsection{Benchmarking}

Benchmarking is the process of analyzing the best products and processes of leading competitors in the same industry, or leading organizations in other industries, using similar processes. It is seen as one of the critical success factors for CRM implementation. Within this regard, benchmarking can be considered as an upper level CRM related practise in which, the steps of leading competitors or leading organizations (in or outside the industry) are followed to actively supports and promotes the implementation of CRM, providing information, material resources, and political support. According to Ocker and Mudambi, (2003), organizations undertaking CRM projects with a dedicated high-level champion were twice as likely to report that their project was doing at least better than expected (Ocker and Mudambi, 2003). Therefore, the following four-item scale that has been suggested by Ahire et al. (1996) has been used to measure the extent of benchmarking construct by tourism organizations:

1. Emphasis on benchmarking competitors' products and processes,

2. Emphasis on benchmarking non-competitors' products and processes,

3. Effectiveness of benchmarking in customer service improvement, and

4. Effectiveness of benchmarking in service cost reduction.

\subsubsection{CRM Software Selection and integration}

CRM optimizes interactions with customers and suppliers. The CRM software gathers and arranges customer information so that it can be used to build customer loyalty and increase customer value (Krueger, 2000; Ranjan and Bhatnagar, 2011). Therefore, before buying the CRM software, the firm should assess its goals and 
decide which customer information to collect and what to do with it. The search for a software package should come last in a series of sequential steps (Umashankar, 2001). However, one of the common mistakes is to choose a CRM package first and then try to map company business processes to fit with it.

CRM software should also be integrated with the backend system(s). A comprehensive management of marketing, sales and service processes requires the integration of interactive processes in the front-office with the transaction-oriented processes in the back-office. Enhancing productivity and efficiency in a company's back-office is the aim of Enterprise Resource Planning (ERP) systems while CRM systems aim to improve customer relationships in the front-office (Pushmann and Alt, 2001). This view is supported by the findings of Umashankar (2001), where 47 percent of firms within his study confirmed that the ability to access all relevant customer information is the biggest challenge in implementing CRM (Umashankar, 2001). Accordingly, the researchers developed the following scale to measure the selection and integration of CRM software:

1. Adequate software selection,

2. Integration with other software,

3. Using CRM software to respond to customer, and

4. Information technology infrastructure.

\subsubsection{Customer Orientation}

Successful CRM implementation focuses on understanding customer needs and desires and integrating them with the organization strategy, technology and business processes (Greenberg, 2010; Gupta and Shukla, 2001; Lukkari, 2011). True success is created when the company apply the best technology that enables the best processes to be executed by the best people. Customer involvement in defining the business processes is highly required as involving the customer will help in making any process changes.

One of the key factors for CRM success is to focus on customers, their needs and to listen to their complaints. Customers are more impatient than ever for answers to their questions and solutions to their problems. Based on results from Cho et al. 
(2002), issues related to customer service were found to be the biggest reason behind customer complaints and dissatisfaction. The lack of a rapid response will increase the intensity of the original complaint. Faster feedback responses in an accurate and kindly manner should be provided. If a customer cannot obtain a "satisfactory response" it is possible for him/her to locate another customer service representative in a reasonable period of time. Hence, the following four-item scale has been developed to measure to assess the customer focus:-

1. Customer satisfaction monitored regularly,

2. Extent of customer satisfaction survey feedback given to managers,

3. Decrease in complaint, and

4. Extent of the use of customer feedback to improve product quality.

\subsubsection{Customization}

In response to the growing threat from competitors, companies are now trying to use information technologies (IT) to deliver new products or to complement traditional ones in a way that meet customers' preferences. CRM holds the promise to achieve such corporate objectives in this highly competitive arena. It involves the continuous use of refined information about current and potential customers in order to anticipate and respond to their needs and draws on a combination of business processes and IT software to discover and construct knowledge about customers (Eid, 2007). With such effective use of information and communication technologies, organizations can offer their customer a variety of personalized products and services (Laudon and Traver, 2001). In order to market effectively to individual customer, companies gather information from both internal and external sources, and use it to provide a unified view (or profile) of the customer for targeted marketing purposes. Therefore, the effective management of information and knowledge is central and critical to the concept of CRM for product tailoring and service innovation and the development of mass customization (Gillies et al., 2002; Ranjan and Bhatnagar, 2011). Customer customization is the key to making the customer the CRM design point. Accordingly, the following four-item scale has been developed to evaluate the personalization efforts:

1. Personalized the transactions,

2. Personalized quality services in every customer touch point at any time, 
3. Using CRM to design and customize products/services, and

4. Motivate and create a knowledge orientation and customer centric culture.

\subsubsection{Training}

Winning the commitment to CRM concept at all levels in an organization is important to reduce resistance and improve usability. Therefore, a critical component in the CRM implementation phase is training. It helps employees to better understand different system operations, as well as the benefits that they will obtain from using the system. CRM implementation may involve major IT and business processes changes that all users must fully understand, accept and master.

A solid training program will go a long way in helping employees to understand not only the goal of CRM, but also to understand how the system will help to better serve customers. While it seems obvious that training of line-level employees is required, it is equally important to thoroughly train managers who will be using CRM to assist in decision making. However, while some of the tools used in a CRM project may seem to generate amazing information, the results must not be taken for granted. Training that includes both fundamental analysis and software operation will be critical for those using the tools to assist in high-level decision making (Bose, 2002). These important aspects of training were captured in the following five-item scale:

1. Employees training,

2. Availability of resources for training,

3. Frequency of training and retaining an employee,

4. Satisfaction of employees with overall training, and

5. Number of employees trained in basic CRM concepts.

\subsubsection{Data Mining}

The success of customer relationship marketing heavily depends on the collection and analysis of customer information that is used for developing highly personalized offerings. CRM is an effective way to maintain customer database, which allows a company to best understand customer's needs - particularly their relationship needs - better than the competitors (Rajnish et al., 2007). With effective 
implementation of CRM databases, companies will be able to re-establish contacts with customers, and will be able to work successfully towards increasing customer retention, repeat sales, and customer referrals (Zineldin 2006). According to Winer (2001) a necessary first step to a complete CRM solution is the building of a customer database or information files as this is the foundation for any CRM activities.

The success or failure of data mining projects requires the involvement of expertise in data mining, company data, and the subject area concerned. As stated by Feelders et al. (2000), despite the attractive suggestion of fully automatic data analysis, knowledge of the processes behind the data remains indispensable in avoiding the many pitfalls of data mining (Feelders, 2000). However, the database should contain information about: Transactions (which should include a complete purchase history and details), customer contacts (which should include all customer contact points), descriptive information, and a response to marketing stimuli - which should contain whether or not the customer responded to a direct marketing initiative, a sales contact, or any other direct contact (Winer, 2001; p:92). Hence, for the purpose of conducting this research, the researchers developed and used the following items to measure data mining:

1. Information about the availability of other product/service that you market,

2. Gather customer information through customer observation and/or interaction,

3. Store customer information in business books and/or files,

4. Effective management of information and knowledge, and

5. Availability of the customer data to managers.

\section{RESEARCH METHODOLOGY:}

\subsection{Research design:}

To empirically validate the research 8 constructs, a positivist research philosophy was utilized with a quantitative approach, in which quantitative data was collected based on survey strategy through questionnaires to address different levels of the study. A survey instrument was developed. Items for all constructs were measured on a 5-point Likert scale (where: $1=$ Not at All, $2=$ Minor, $3=$ Moderate, $4=$ Major, and $5=$ Critical). The intention was to keep the questions as short as possible 
and to use simple, clear, concise and unambiguous language to aid the participants' understanding. There was therefore no requirement for the respondents to do anything other than tick (check) predefined response boxes.

However, the respondents have been offered a "Not Applicable" option for each item to be checked if some items are not applicable to their tourism organization. Since no replies were received stating "Not Applicable" this option is not shown in the findings tables. It is important though to mention that this is an indication of the respondents' confidence in their answers.

\subsubsection{Research instrument development Measures}

Two consecutive rounds of pre-testing were conducted in order to insure that respondents could understand the measurement scales used in the study: First, the questionnaire was reviewed by 8 academic researchers experienced in questionnaire design and tourism research and next, the questionnaire was piloted with two CRM experts known to the researchers and 11 tourism organizations located in Cairo. The pilot took the form of an interview where the participants were first handed a copy of the questionnaire and asked to complete it and then discuss any comments or questions they had. The outcome of the pre-testing process was a slight modification and alteration of the existing scales, in light of the sales context under investigation.

\subsubsection{Data Collection:}

The generalizability of the study relied on the representativeness of the respondents. The survey questionnaire targeted a sample of 547 tourism organizations operating in Egypt that had been selected randomly from a population of 2735 tourism organizations [as the units of analysis used in the pilot study - 11 tourism organizations - were excluded from the population frame (2746) when calculating the sample size as well as the response rate]. The population frame was generated from the Egyptian Ministry of Tourism, Egyptian Champer of Commerce and The Egyptian Cabinet Information and Decision Support Center (IDSC) databases which contained the needed information about tourism organizations operating in Egypt. The population frame was generated to include only 
organizations that can satisfy the essential requirement to be considered as a unit of analysis.

The sample size was planned to be determined according to the Aaker and Day (1986) sample size equation which is highly accepted by social science researchers since it takes into account the degree of required confidence, the sample error, ratio of population characteristics available in the sample $(50 \%$ in social sciences) and population size. According to Aaker and Day (1986) the sample size can be determined depending on the following equation:-

$$
S=Z \sqrt{\frac{p(1-p)}{n}} \sqrt{\frac{N-n}{N-1}}
$$

Where: -

$\mathrm{Z}=$ Degree of required confidence (95\%)

$S=$ Sample error (5\%)

$\mathrm{P}=$ Ratio of population characteristics available in the sample $(50 \%)$

$\mathrm{N}=$ Population size

$\mathrm{n}=$ Sample size"

Although the sample size was planned to be determined according to the Aaker and Day (1986) sample size equation, as the sample size generated by the Aaker and Day (1986) sample size equation was relatively small, the sample was chosen to represent $20 \%$ of the population frame not only as accepted by most researchers within the field but also to increase the sample confidence and decrease the sample error.

Simple random sample technique was used in selecting the research sample out of the population frame as it is the most basic form of probability sample where each unit of the population frame has an equal probability of inclusion in the sample (Bryman and Bell, 2011). As the sample size was chosen to represent $20 \%$ of the population, the sampling fraction was equal to $0.2(547 / 2735)$ and SPSS was used to generate the needed sample. The selection of the sample included local tourism organizations, foreign tourism organizations and joint tourism organizations. All the selected tourism organizations had implemented the CRM system at least 5 year 
ago. A research packet, which contained a covering letter and an anonymous (selfadministering) questionnaire, was mailed to the head of marketing departments; customer services officers or customer relationship managers that were users of the CRM system (547 in total). This procedure resulted in 162 usable respondents with a $30.45 \%$ overall response rate. The response rate was calculated using the method proposed by De Vaus (1991: 99). The 162 usable respondents were well distributed among the research population frame which reflects not only that the sample is representative for its population, but also increase the generalizability of the research findings.

Although Bartlett, Kotrlik \& Higgins (2001) argued that when determining the sample size for a SEM research, 10 observations per each indicator (independent variable) is traditionally recommended, Westland (2010) illustrated that the requisite sample size is not a linear function solely of indicator count (Westland, 2010; P476). Since the sample size of 162 cases is not sufficient to support a structural equation model at the level of complete disaggregation of measured variables (by using the multiple measured variables as indicators for each construct), the researcher used the factor scores as single item indicators and performed a path analysis, applying the maximum likelihood estimates (MLE) method, following the guidelines suggested by Joreskog and Sorbom (1982) and supported by El-Gohary (2009) and El-Gohary (2012).

However, there are some general guidelines that have been proposed by some researchers with regards to the suitable sample size to be used when using structural equation modeling in data analysis. For example, Hair et al (1998) suggest that a sample with a size of less than 100 is considered to be a small sample. They also suggest that a medium sample size is between 100 and 200, and a large sample size in more than 200. Meanwhile, Garson (2009) suggest that a sample size has to be more than 100. Moreover, many researchers have used a sample size of around 100 to conduct research using structural equation modeling (e.g. Khong, 2005, Eid 2007, El-Gohary 2009 and El-Gohary 2012). Based on that, it is generally regarded that a sample size of 100 is the practical acceptable size for using structural equation 
modeling. Accordingly, the current research sample size is a practically acceptable size for employing SEM.

Based on the descriptive analysis of the data collected through the survey it was found that the majority of the respondents were involved in CRM implementation $(89.81 \%)$, most were younger than 40 years old $(68 \%)$, and a few respondent (approximately $3.1 \%$ ) were more than 50 years old. With respect to years of working with CRM, approximately $58 \%$ of the sample had used CRM for less than 5 years, and $42 \%$ had used it for a period between 5 and 10 years. In terms of ownership, the majority of the respondents $(71.7 \%)$ were members of local tourism organizations, $24.5 \%$ were members of joint tourism organizations and the minority $(3.8 \%)$ were members of foreign tourism organizations. Finally, more than half of the respondents hold the position of customer service manager in their organizations $(51.1 \%)$. Meanwhile, $34.6 \%$ hold the position of marketing manager, $7.4 \%$ hold the position of sales manager and $6.9 \%$ are IT manager. These responses formed the basis for refining and validating the scales for the CRM constructs.

To ensure that the valid responses were representatives of the larger population, a non-response bias test was used to compare the early and late respondents. $\chi^{2}$ tests show no significant difference between the two groups of respondents at the $5 \%$ significance level, implying that a non-response bias is not a concern.

\section{SCALE REFINEMENT AND VALIDATION}

Before building a model that will consider all the CSFs together, it is important to highlight, from a methodological point of view, which individualised analyses of each of those dimensions will be made, in order to carry out a prior refinement of the items used in their measurement. It is also necessary to indicate that, as recommended by Anderson and Gerbing (1982), prior to testing the full latent model, an exploratory factor analysis (EFA) was conducted using the maximum likelihood method and Varimax rotation. Eight distinct factors emerged (jointly accounting for $82.1 \%$ of the variance). 


\subsection{The Exploratory Factor Analysis (EFA):}

The 34 items measuring the CRM critical success factors were subjected to principal component factor analysis. Eigenvalues and scree plot were used to determine the number of factors to be extracted. An eight-factor structure was suggested using the criteria of an eigenvalue greater than 1 , and the extracted factors account for $82.1 \%$ of the total variance. All factor loadings are generally high, and the lowest loading is equal to 0.703 , while the Kaiser-Meyer-Olkin test of the factor analysis is substantial [0.742]. The resulting factor loadings are shown in table (1) with all factor loadings less than 0.5 suppressed. All items loaded onto the expected factors as they were originally designed. Factor loading were all higher than 0.5 on its own factors and, therefore, each item loaded higher on its associated construct than on any other construct. This supported the discriminant validity of the measurement.

Please insert Table 1 about here

\subsection{The Confirmatory Factor Analysis (CFA):}

The Confirmatory factor analysis (CFA) approach has been used to refine and validate the CRM constructs. CFA is suggested as a precise method to test the unidimensionality and validity of measurements (Gerbing and Anderson, 1988; Yang and Peterson, 2004; Tellefsen and Thomas, 2005; Wu and Wu, 2005; Hair et al., 2006). CFA gives strong support for how well the measured items represent the constructs (Hair et al., 2006:770). CFA supports the validation of research constructs and tests how well our specification of the factors matches reality (the actual data). The adequacy of the measurement models was evaluated on the criteria of overall fit with the data, convergent validity and discriminant validity (Liang and Wang, 2004). To conduct CFA, a measurement model consisting of the collection of scales is first determined.

Validity analysis was conducted for all the scales along the four major dimensions: content validity, convergent validity, discriminant validity, and criterion- 
related validity. According to Flynn (1994) a construct will be valid if it is unidimensional and statistically reliable. Therefore, for each of the scales, the researchers conducted unidimensionality test and reliability analysis.

\subsubsection{Content Validity Analysis:}

Content validity is the degree to which the domain of properties or characteristics of a concept one desire to measure are in fact captured by the measures (Bagozzi, 1994). However, the scale must be tested for content validity before any further refinement or validation is undertaken. Inadequate content validity indicates that the items in an instrument do not properly measure the construct and that the analysis undertaken is meaningless. An instrument has content validity if there is a general agreement among the subjects and researchers that the instruments has measurement items that cover all the content domain of the variables being measured (Nunnaly and Bernstein, 1994). According to McDaniel and Gates (1996), if items corresponding to various constructs of an instrument are derived from comprehensive analysis of relevant literature, content validity can be achieved. The discussion in the previous section on development of Research Constructs reflects the genesis of the current research constructs in relevant literature, and thus, established the content validity of the research instrument.

\subsubsection{Undimensionality Analysis:}

According to Ahire et al. (1996) items in unidimensional scale measure one single construct. A researcher can reduce the problems related to unidimensionality by carefully selecting the items for the scales. Tests for the unidimensionality of scales were performed using confirmatory factor analysis involving a single factor representation each set of congeneric items.

A measurement model has been developed for each construct to use the CFA for unidimensionality testing. In this model, individual items making up the construct are checked to find out how closely they represent the same construct. A goodness of fit index of 0.90 or higher for the model suggests that there is no evidence of lack of unidimensionality. The unidimensionality test results for 8 scales are summarised in table 1. Several fit statistics were utilized to evaluate the acceptability of each of 
the factor models. As recommended by Bentler and Bonnet (1990), the normed fit index (NFI) was utilized and deemed acceptable if above the recommended value of 0.90. Additionally, the comparative fit index (CFI) also was used and acceptable model fit is demonstrated with CFls above 0.90, as well. Furthermore, goodness-of-fit index (GFI), adjusted goodness-of-fit index (AGFI), and root mean square residual (RMR) also were provided. Standard cut-offs for the above indices, as proposed by experts, are provided in Table 2. The results indicated that the scales were unidimensional.

\section{Please insert Table 2 about here}

\subsection{Reliability Analysis:}

The psychometric properties of the constructs were assessed by calculating the Cronbach's alpha reliability coefficient and the items-to-total correlation (Nunnally \& Bernstein, 1994). These coefficients are represented for each of the constructs in (Table 2). All scales have reliability coefficients ranging from 0.845 to 0.966 , which exceed the cut-off level of 0.60 set for basic research (Nunally, 1978).

However, the internal consistency approach is relevant to this study because Likert scales are used to measure the variables. Churchill (1979) stated that this approach is relevant to multiple-item scale, which consists of at least three items. Hence, Cronbach Alpha has been computed to evaluate the reliability of all scales that consists of three items or more. The cronbach's alpha values for each scale are provided in Table 3. All of the scales had an acceptable reliability in their original form.

Please insert Table 3 about here

\subsection{Convergent Validity Analysis:}


Convergent validity describes the extent to which indicators of a specific construct converge or share a high proportion of variance (Hair et al., 2006). Convergent validity can be assessed by three criteria (Fornell and Larcker 1981; Anderson and Gerbing, 1988; Kim, 2003; Liang and Wang, 2004; Tellefsen and Thomas, 2005; Hair et al., 2006; Tabachnic and Fidell, 2007; Chow and Chan, 2008; Hooper et al., 2008; Čater and Čater, 2010). Firstly, factor loading for an item is at least 0.7 and significant. Secondly, construct reliability is a minimum of 0.7 (See table 3). Finally, average variance extracted (AVE) for a construct is larger than 0.5. Table 4 summarize the results of the convergent validity analysis. Note that all of the scales had an acceptable convergent validity.

Please insert Table 4 about here

\subsection{Discriminate Validity Analysis:}

Discriminant validity is the distinctiveness of two conceptually similar constructs (Hair et al., 2006). There are two criteria to assess the discriminant validity among constructs (Kim, 2003; Yang and Peterson, 2004; Wu and Wu, 2005). Discriminant validity among factors exists firstly when the alpha coefficients are greater than their correlation coefficients (Gaski, 1984; Eisingerich and Bell, 2007) and secondly, when the square root of AVE (average variance extracted) of each construct is generally higher than the correlations between it and any other constructs in the model (Fornell and Larcker, 1981; Hair et al., 2006; Wang et al., 2006; Coltman, 2007).

Correlation matrix and square root of AVE were used to assess the discriminant validity of constructs. To meet the requirements for satisfactory discriminant validity, the square root of AVE of each construct should be higher than the correlations between any combinations among any two pairs of constructs in the model as recommended by Fornell and Larcker (1981). This indicates that each construct should share more variance with its items than it shares with other constructs. Table 5 illustrates that the square root of the average variance extracted $(\mathrm{AVE})$ for the 8 constructs are greater than any correlation between any combinations 
among any two pairs of these constructs. As can be seen from table 5, the square root of variances extracted by constructs was greater than any correlation among constructs; this implied that the research constructs were empirically distinct and confirmed the discriminate validity of these constructs.

\section{Please insert Table 5 about here}

\subsection{Criterion-related Validity}

Criterion-related Validity refers to the extent to which the measurement instrument is able to predict a variable - an assigned criterion. Criterion-related validity is the degree of correspondence between measures and some other accepted measured measure. Bagozzi (1994) describe this as: the degree of connectedness of a focal measure with other measures. To assess the criterionrelated validity of various constructs, the scale scores were correlated with the primary construct CRM success. Table 4 shows that all of the scales have statistically significant positive correlation. Therefore, criterion-related validity is supported for all of the research scales. These significant positive correlations also have major implications for marketing people, as they suggest the notion that the CRM critical success factors (CSFs) should be implemented holistically rather than piecemeal to get the full potential of the CRM.

\subsection{An Integrative CRM Implementation Framework}

One of the main objectives of this study is to set a valid structure for CRM implementation constructs and to carry out an initial investigation of the relationships, if any, among these constructs. According to this research, there are eight constructs constitute a comprehensive CRM implementation model. To confirm or reject the proposed research theory in this study, the second-order- hypothesised CRM model was run.

The eight factors are grounded in CRM and the related literatures. Although several scholars argue that CRM is a multidimensional construct, there is no 
agreement among scholars about these dimensions. However, the current study is one of the studies that seek to set a valid structure of a comprehensive CRM model. To assess the goodness of fit of the second-order proposed constructs of the CRM implementation the researchers run the CFA test. Table 6 illustrates the obtained fit indices of the model.

Please insert Table 6 about here

The results of this model showed satisfactory results, which indicates that model fit was adequate, therefore a specification of the structural model was deemed appropriate. Finally, average variance extracted (AVE) for the CRM constructs is 0.78 which is greater than the acceptable level (0.5). This finding supports the idea that CRM constructs are correlated together and should be considered together.

\section{DISCUSSION AND IMPLICATIONS}

This research aimed to: (a) Identify CSFs constructs of CRM implementation in developing economies and develop scales of measuring these scales and (b) Carry out an initial investigation of the relationships, if any, among these CRM constructs. The study provides new theoretical grounds for studying CRM as well as CRM implementation in developing economies. It also supplies tourism organizations with a number of operative CSFs that may be essential if they are to remain competitive in the dynamic marketplace that they currently operate in. Not only does this study provide an empirical assessment of the essential constructs in CRM implementation, but it also assesses the critical success factors that were distilled from a comprehensive review of the relevant literature.

The findings confirmed that to achieve strategic advantages, top management should be personally knowledgeable of the CRM potential and proactively involved in its internal diffusion in order to manage it effectively. This goes in line with the findings of Al-Qirim (2006), Al-Qirim (2007), Damaskopoulos and Evgeniou (2003), Lal (2005), Yu (2006), Fillis, et al (2004), Mirchandani and Motwani (2001), 
Lertwongsatien and Wongpinunwatana (2003), Seyal and Abd Rahman (2003), Tsao, Lin, and Lin (2004), Stylianou et al (2003) and Looi (2004). It also goes in line with the findings of (Daniel and Myers, 2000), who found that new information technology systems will only succeed if there is support from senior management.

The findings also confirmed that using CRM for marketing purposes should be based on clear goals. Nevertheless, successful implementation of the CRM depends on how clearly defined the strategic goals are for an organization. This goes in line with the findings of Cho et al., (2002) and Ranjan and Bhatnagar (2011) who found that a clear strategy that focuses on the goals of maintaining customer loyalty and using complaint-handling data to solve the different problems and address issues raised by customers is required for successful CRM implementation. It also supports the findings of Umashankar (2001) who confirmed that CRM initiatives require vision and each and every employee within the organization must understand the purpose and changes that CRM will bring. Moreover, the findings support the arguments of Morgan and Inks (2001) who illustrated that in situations where employees know exactly what to expect from system implementation, the process of CRM system acceptance will be smoother and more effective. This research argues that, while both technology and business processes are both critical to successful CRM initiatives, it is the individual employees who are the building blocks of customer relationships.

Meanwhile, the findings also found that personalization, customer orientation training, benchmarking and data mining do play a critical role to successfully implement the CRM system. This does in line with the findings of Chen and Popovich (2003), who found that the organization management must show high level of commitment to an ongoing company-wide education and training program to achieve successful CRM implementation. The findings also support the findings of: Ocker and Mudambi (2003), Ahire et al. (1996), Greenberg (2010), Gupta and Shukla (2001), Lukkari (2011), Gillies et al., (2002), Ranjan and Bhatnagar (2011) and Rajnish et al., (2007). 
Moreover, the findings show that acquiring a better understanding of existing customers allows companies to interact, respond, and communicate more effectively and to significantly improve retention rates. The results clearly demonstrated that CRM CSFs have catalytic influence on CRM success. Overall, the CSFs variables, explain $60.3 \%$ of CRM success. This result supports the theoretical view of $\mathrm{Xu}$ (2002) that CRM implementation ensures customer satisfaction and retention by solving customer problems quickly.

Finally, the results of this study have major implications for marketing people, as they suggest the notion that the CRM critical success factors CSFs should be implemented holistically rather than piecemeal to get the full potential of the CRM.

\section{Limitations and Suggestions for Future Research}

As with any study, there are certain limitations that should be recognized. First, the researchers assessed CRM CSFs using only 8 constructs; top management support, CRM strategy, benchmarking, CRM software selection, customer orientation, customization, training and date mining; while there is evidence that CRM is a much broader concept that includes more constructs such as: customer loyalty (Jutla et al., 2001) and satisfaction (Palmer et al., 2005). Second, the present study relied on a sample of tourism organizations managers and, consequently, the researchers cannot afford to generalize the findings in other types of businesses. Third, the data are cross-sectional in nature and hence it is not possible to determine causal relationships.

The direction for future research, which emerged from the research findings, is to improve our understanding of these CSFs in other types of business. For example, each CSF discussed in this study warrants more in depth study. While some CSFs has been recurring issues in marketing, information technology and management information system research, their implications for CRM requires a new perspective. Given the high costs associated with the implementation of CRM systems, a potentially fruitful area would be to develop the quantification of CSFs into an "index of practice" so that companies could determine the level of performance on a timebased approach. The results from an audit, with regard to the index, could pinpoint 
areas that need attention and improvement. Future researchers may choose to focus on one or more of the CSFs to generate an in-depth knowledge to inform both theoretical and practical applications. Researchers could use these factors to assess the success of companies. Meanwhile, these CSFs must be subjected to review, critique, and discussion for an extended period before getting general acceptance. Additional items might be tried in each category. Finally, different constructs could be tried to measure CRM success. To this end, a very promising research approach is the development of a model that explains how CRM technology influences variables such as: customer loyalty (Jutla et al., 2001), business development (Hart et al., 2004) and customer satisfaction (Bueherer et al., 2005).

\section{REFERENCES}

Aaker, D. A. \& Day, G. S. (1986). The perils of high-growth markets. Strategic Management Journal, 7 (5), 409-421.

Abbott, J., Stone, M. and Buttle, F. (2001). Integrating customer data into customer relationship management strategy: An empirical study. Journal of Database Marketing, 8 (4), 289-300.

Abdelhamed, M. \& Elhousaney, N. (2009). Social and cultural variables affecting the quality of eco-tourism in Fayoum, Faculty of Social Work, Fayoum University, Retrieved September 18, 2011, from Fayoum University website:

http://www.aun.edu.eg/conferences/27 9 2009/ConferenceCD files/Papers/55.pdf

Ahire, S., Golhar, D. Y. \& Waller, M. A. (1996). Development and validation of TQM implementation construct. Decision Sciences, 27, 23-56.

Al-Mashari, M. \& Zairi, M. (2000). The Effective application of SAP R/3: A Proposed Model of Best Practice. Logestics Information Management, 13 (3), 156-166.

Al-Qirim, N. (2006). Personas of E-Commerce Adoption in Small Businesses in New Zealand. Journal of Electronic Commerce in Organizations, 4 (3), 18-45.

Al-Qirim, N. (2007). Personas of e-commerce adoption in small businesses in New Zealand. Web Technologies for Commerce and Services Online, 286-310.

Anderson, J. \& Gerbing, D.(1988). Structural equation modeling in practice: a review and recommended two-step approach. Psychological Bulletin, 103 (3), 11-423.

Anderson, J. C. and D. W. Gerbing (1982). Some Methods for Respecifying Measurement Models to Obtain Unidimensional Construct Measurement, Journal of Marketing Research 9 (4): 453-460.

Anosike, U. P. and Eid, R., (2011), Integrating Internal customer orientation, Internal Service Quality and Customer Orientation in the Banking Sector: An Empirical Study, The Service Industries Journal, 31(14): 2487-2505.

Avlonitis, G. J. \& Panagopoulos, N. G. (2005). Antecedents and consequences of CRM technology acceptance in the sales force. Industrial Marketing_Management, 34 (4), 355-368. Bartlett, Kotrlik, \& Higgins. (2010). Organizational research: determining appropriate sample size in survey research. Information Technology, Learning, and Performance Journal, 19 (1), 43-50.

Bagozzi, R. (1994). Principles of Marketing Research. London, Basil Blackwell Ltd.

Bell, J. (1996). Doing Your Research Project: A Guide for First-Time Researchers in Education and Social Science. Buckingham, Open University Press.

Bentler, P. M. (1990). Comparative Fit Indexes in Structural Models. Psychological Bulletinm, 107, 238-246. 
Bhaskar, R. (2004). A Customer Relationship Management System to Target Customers at Cisco. Journal of Electronic Commerce in Organisations, 2 (4), 63-73.

Bose, R. (2002). Customer relationship management: key components for IT success. Industrial Management \& Data Systems 102 (2), 89-97.

Bryman, A. \& Bell, E (2001). Business Research Methods, Oxford University Press, Oxford, UK

Čater, T. \& Čater, B. (2010). Product and relationship quality influence on customer commitment and loyalty in B2B manufacturing relationships. Industrial Marketing Management, 39 (8), 1321-1333.

Chan, O. J. (2005). Toward a Unified Veiw of Customer Relationship Management. Journal of American Academy of Business, 6 (1): 32-38.

Chen, I. J. \& Popovich, K. (2003). Understanding customer relationship management (CRM): People, process and technology. Business Process Management Journal, 9 (5), 672-688.

Cho, Y., Im, I., Hiltz, J. \& Fjermestad, J. (2002). An Analysis of Online Customer Complaints: Implications for Web Complaint Management. Proceedings of the 35th Hawaii International Conference on System Sciences.

Chow ,W. \& Chan ,L.(2008). Social network, social trust and shared goals in organisational knowledge sharing. Information \& Management, 45 (7), 458-465.

Churchill, G. A. (1979). A Paradigm for Developing Better Measures of Marketing Construct.Journal of Marketing Research, XVI (February), 64-73.

Coltman, T. (2007). Why build a customer relationship management capability?. Journal of Strategic Information Systems, 16 (3), 301-320.

Cooper, D. \& Emory, C. (1995). Business Research Methods. Chicago, Irwin.

Nunnally, J. a. \& Bernstein, I. H. (1994). Psychometric Theory. 3rd Ed, London, McGraw Hill.

Damaskopoulos, P., \& Evgeniou, T. (2003). Adoption of new economy practices by SMEs in Eastern Europe. European Management Journal, 21 (2), 133-145.

Daniel, E. \& Myers, A. (2000). Levelling the playing field: electronic commerce in small and medium enterprises. Retrieved December 5, 2009, from: www.cranfield.ac.uk/som/ecom

Davenport, T. H. \& Short, J. E. (1990). The new industrial engineering: information technology and business process design. Sloan Management Review, 31 (4), 11-27.

De Vaus, D. A. (1991). Surveys in social research. Allen and Unwin, Sydney.

Dubrovski, D. (2001). The Role of Customer Satisfaction in Achieving Business Excellence. The 6th TQM World Congress.

Egyptian Ministry of Tourism (2011). Egyptian Tourism Statistics, Retrieved June 2, 2011, from Egyptian Ministry of Tourism Web site:

http://www.tourism.gov.eg/Pages/Tourismlndicators.aspx.

Eid, R., (2007), Toward a Successful CRM Implementation In banks: An Integrated Model. The Service Industries Journal, 27(8), 1021-1039.

Eisingerich, A. \& Bell, S. (2007). Maintaining customer relationships in high credence services. Journal of Services Marketing, 21 (4), 253-262.

El-Gohary, H, Edwards, D., and Huang, J (2013), Customer Relationship Management (CRM) Practices by Small Businesses in Developing Economies: A Case Study of Egypt, International Journal of Customer Relationship Marketing and Management (IJCRMM), 4 (2), pp: 1-24.

El-Gohary, H, (2012). Factors affecting E-Marketing adoption and implementation in tourism firms: An empirical investigation of Egyptian small tourism organizations, Tourism Management, 33 (5), 1256-1269.

El-Gohary, H, (2011), Customer Relationship Management Adoption in Developing Economies: The Case of Egyptian Small Business Enterprises, ISBE 2011 Conference, Sustainable Futures: Enterprising Landscapes and Communities, Sheffield, UK, 9-10 November 2011.

El-Gohary, H, (2009). The impact of E-Marketing Practices on Marketing Performance of Small Business Enterprises: An Empirical Investigation (Unpublished doctoral dissertation). Bradford University, Bradford, West Yorkshire, UK. 
Fakhry, A. (2006).Pharaonic Egypt: A brief history of Egypt since ancient times to the year 332 BC, 21st ed, Cairo, Egypt, Anglo-Egyptian Library.

Feelders, A., Daniels, H. \& Holsheimer, M., (2000). Methodological and practical aspects of data mining. Information \& Management, 37 (5), 271-281.

Fillis, I., Johannson, U., \& Wagner, B. (2004). Factors impacting on e-business adoption and development in the smaller firm. International Journal of Entrepreneurial Behavior \& Research, 10 (3), 178-191.

Fornell, C. \& Larcker, D. (1981). Evaluating structural equation models with unobservable variables and measurement error. Journal of Marketing Research, 18 (1), 39-50.

Flynn, B. B., Schroeder, R. G. \& Sakakibara, S. A. (1994). A Framework for Quality Management Research and an Associated Instrument. Journal of Operation Management, 11,339-366.

Garson, D. (2009). Path analysis. Retrieved June 2, 2011, from David Garson Web site: http://faculty.chass.ncsu.edu/garson/PA765/path.htm.

Gaski, J.(1984). The theory of power and conflict in channels of distribution. Journal of Marketing, 48 (3), 9-29.

Gillies, C. \& Rigby, D. \& Reichheld, F. (2002), "The story behind successful customer relations management ", European Business Journal, 14 (2) 73-77.

Greenberg, P. (2010). The impact of CRM 2.0 on customer insight. Journal of Business \& Industrial Marketing, 25 (6), 410 - 419

Gupta, M. \& Shukla, S. (2001). Implementation Issues in CRM: A Study in the Indian Banking Sector. Productivity, 42 (1), 26-38.

Hair, J., Black, B, Babin, B., Ralph, A. \& Ronald, T. (2006). Multivariate Data Analysis, 6th edition, London: Prentice-Hall.

Hair, J., Ralph, A., \& Ronald, T. (1998). Multivariate data analysis (5th ed.). London:

Prentice-Hall.

Hande Kimiloglu, H. \& Zarali, H., (2009). What signifies success in e-CRM?. Marketing Intelligence \& Planning, 27 (2), $246-267$.

Harrigan, P., Ramsey, E. \& Ibbotson, P. (2011). Critical factors underpinning the e-CRM activities of SMEs. Journal of Marketing Management, 27 (5\&6), 503-529.

Hart, S., Hogg, G. \& Banerjee, M. (2004). Does the level of experience have an effect on CRM programs? Exploratory research findings. Industrial Marketing Management, 33, 549560.

Heygate, R. (1999). CRM 123, CRM Resources. IEEE Computer Society.

Hooper, D., Coughlan, J. \& Mullen, M. (2008). Structural Equation Modelling: Guidelines for Determining Model Fit. The Electronic Journal of Business Research Methods, 6 (1), $53-60$. Injazz, D. and Karen, P. (2003), Understanding customer relationship management (CRM), Business Process Management Journal, 9 (5), 672-689.

Johnson, J. (2004). Making CRM Technology Work. British Journal of Administrative Management, 39, 22-23.

Jöreskog, K. G., \& Sörbom, D. (1982). Recent developments in structural equation modeling. Journal of Marketing Research, 404-416.

Jutla, D., Craig, J. \& Bodorik, P. (2001). Enabling and Measuring Electronic Customer Relationship Management Readiness. Proceedings of the 34th Hawaii International Conference on System Sciences.

Karakostasa, B., Kardarasb, D. \& Papathanassiou, E. (2004). The state of CRM adoption by the financial services in the UK: an empirical investigation. Information \& Management, 42 (6), 853-863.

Khong, K. W. (2005). The perceived impact of successful outsourcing on customer service management. Supply Chain Management: An International Journal, 10 (5), 402-411.

Kim, J.(2003). An Integrative Model of E-Loyalty Development Process: The Role of ESatisfaction, E-Trust, Etail Quality and situational factors. MSc, Oklahoma State University, USA. 
Kincaid, J. W. (2003), Customer Relationship Management: Getting it Right!, Prentice-Hall PTR, Upper Saddle River, NJ.

Krueger, M. (2000). Fulfillment: The Gateway to Customer Loyalty. Manufacturing Systems, $18(9)$.

Lal, K. (2005). Determinants of the adoption of e-business technologies. Telematics and Informatics, 22 (3), 181-199.

Laudon, K. \& C. Traver (2001). E-Commerce: Business. Technology. Society., AddisonWesley Longman Publishing Co., Inc. Boston, MA, USA.

Law 141 (2009). Law number 141 for the year 2009, The Small Business Enterprises Development Law, In Law (Ed.): Elmatabea Elameriah, Cairo, Egypt.

Lertwongsatien, C., \& Wongpinunwatana, N. (2003). E-commerce adoption in Thailand: an empirical study of small and medium enterprises (SMEs). Journal of Global Information Technology Management, 6 (3), 67-83.

Liang, C. \& Wang, W. (2004). Attributes, benefits, customer satisfaction and behavioral loyalty- An integrative research of financial services industry in Taiwan. Journal of Services Research, 4 (1), 57-91.

Looi, H. (2004). A Model of Factors Influencing Electronic Commerce Adoption among SMEs in Brunei Darussalam. International Journal of Information Technology 10, 72 - 87.

Lukkari, P., (2011). Merger: institutional interplay with customer relationship management. Management Research Review, 34 (1), 17 - 33

Magnusson, M. (2001). E-Commerce in small businesses: focusing on adoption and implementation. [cited 2/1/2009], Available from: www.hh.se/ide/nwec/pdf/Magnusson.PDF

McDaniel, C. \& Gates, R. (1996). Contemporary Marketing Research. 3rd ed, Minneapolis, Western Publishing.

McKenzie, J. (2001). Serving Suggestions. Financial Management (CIMA). Dec: 26-27.

Mirchandani, D., \& Motwani, J. (2001). End-user perceptions of ERP systems: a case study of an international automotive supplier. International Journal of Automotive Technology and Management, 1 (4), 416-424.

Mulaik, S. (1972). The Foundation of Factor Analysis, New York:MCGraw-Hill.

Ngai, E.W.T. (2005). Customer relationship management research (1992-2002): An academic literature review and classification, Marketing Intelligence \& Planning, 23 (6), 582 605

Nunnally, J. (1978). Psychometric Theory. New York, Mc Graw Hill.

Nunnally, J. \& Bernstein, I. H. (1994). Psychometric Theory. 3rd ed, London, McGraw Hill.

Ocker, R. \& Mudambi, S. (2003). Assessing the Readiness of Firms for CRM: A Literature Review and Research Model. Proceedings of the 36th Annual Hawaii International Conference on System Sciences (HICSS'03).

Parvatiyar, A. \& Sheth, J.N. (2001), Customer relationship management: emerging practice, process, and discipline, Journal of Economic \& Social Research, 3 (2), pp. 1-34.

Peter, J. P. (1979). Reliability: A Review of Psychometric Basis and Recent Marketing Practice. Journal of Marketing Research, XVI (February), 6-17.

Porter, M. (1987). From competitive advantage to corporate strategy. Harvard Business Review, 65 (3), 43-95.

Pushmann, T. \& Alt, R. (2001). Customer Relationship Management in The Pharmaceutical Industry. Proceedings of the 34th Hawaii International Conference On System Sciences.

Rajnish, J., Sangeeta, J. \& Upinder, D. (2007). A scale for measuring customer relationship management effectiveness in service sector. Journal of Services Research, 7 (1), 37-58.

Ranjan, J \& Bhatnagar, V. (2011). Role of knowledge management and analytical CRM in business: data mining based framework. Learning Organisation, 18 (2), 131 - 148.

Seyal, A. H., \& Abd Rahman, M. N. A. (2003). A preliminary investigation of e-commerce adoption in small \& medium enterprises in Brunei. Journal of Global Information Technology Management, 6 (2), 6-26.

Schendel, D. E. \& Hofer, C. W. (1979). Strategic management: A new view of business policy and planning. Boston, MA: Little Brown. 
Sigala, M. (2005). Integrating customer relationship management in hotel operations: managerial and operational implications. International Journal of Hospitality Management, 240 (3), 391-413.

Stokes, D. (2000). Marketing and the small firm. In: CARTER, S. And JONES EVES, D. (Eds.) Enterprise and Small Business: Principles, Practice and Policy. London: Pearson Education Ltd.

Stylianou, A. C., Bobbins, S. S. and Jackson, P. (2003). Perceptions and attitudes about eCommerce development in China: an exploratory study. In: Felix B. TAN, M. G. H. (Ed.) Advanced Topics in Global Information Management: Vol. 3.IGI, p. 295.

Tabachnick, B. \& Fidell, L. (2007). Using Multivariate Statistics. 5th edition, Pearson Education. Inc, USA.

Tellefsen, T. and Thomas, G. (2005). The antecedents and consequences of organisational and personal commitment in business service relationships. Industrial Marketing Management, 34 (1), 23-37.

Tsao, H. Y., Lin, K. H. C. \& Lin, C. (2004). An investigation of critical success factors in the adoption of B2BEC by Taiwanese companies. Journal of American Academy of Business, $\mathbf{5}$ (1), 198-202.

Umashankar, V. (2001). e-CRM - Issues of Semantics, Domain \& Implementation. Productivity, 42 (1), 2001, 19-25.

Wang, E., Ying, T., Jiang, J.\& Klein, G.(2006). Group cohesion in organisational innovation: An empirical examination of ERP implementation. Information and Software Technology, 48 (4), 235-244.

Westland, C. (2010). Lower bounds on sample size in structural equation modelling.

Electronic Commerce Research and Applications, 9 (6), 476-487, November-

December.

Winer, R. S. (2001). A Framework for Customer Relationship Management. California Management Review, 43 (4), 89-105.

Wu, I.-L. \& Wu, K.-W. (2005). A hybrid technology acceptance approach for exploring e-CRM adoption in organisations. Behaviour \& Information Technology, 24 (4), $303-316$.

Xu, Y., Yen, D. C., Lin, B. \& Chou, D. C. (2002). Adopting customer relationship management technology. Industrial Management \& Data Systems 102 (8): 442-452.

Yang, Z. \& Peterson, R. (2004). Customer perceived value, satisfaction, and loyalty: The role of switching costs. Psychology \& Marketing, 21 (10), 799-822.

Yu, C.-S. (2006). Influences on Taiwanese SME E-Marketplace Adoption Decisions. Journal of Global Information Technology Management, 9 (2), 5.

Zablah, A. R., Bellenger, D. N. \& Johnston, W. J. (2004). An evaluation of divergent perspectives on customer relationship management: Towards a common understanding of an emerging phenomenon. Industrial Marketing Management, 33, 475-489

Zineldin, M. (2006). The royalty of loyalty: CRM, quality and retention. The Journal of Consumer Marketing, 23 (7), 430. 
Appendix 1: Constructs, Scale items and sources

\begin{tabular}{|c|c|c|}
\hline Construct & $\begin{array}{c}\text { Measures Used to Capture } \\
\text { Constructs }\end{array}$ & Source \\
\hline $\begin{array}{c}\text { Top Management } \\
\text { Support }\end{array}$ & $\begin{array}{l}\text { - Allocation of adequate resources } \\
\text { to CRM efforts } \\
\text { - Relative importance given by the } \\
\text { top management to CRM } \\
\text { - Relative importance given by the } \\
\text { top management to CRM as a } \\
\text { strategic issue } \\
\text { - Performance measure based on } \\
\text { CRM implementation }\end{array}$ & $\begin{array}{ll}\text { Adopted from } \\
\text { Ahire et al., } \\
(1996)\end{array}$ \\
\hline $\begin{array}{l}\text { Clear CRM } \\
\text { Strategy }\end{array}$ & $\begin{array}{l}\text { - Clear project vision/Scope, } \\
\text { - Change required to start with } \\
\text { CRM } \\
\text { - Clarity of CRM goals } \\
\text { - Developing a Clear CRM Strategy }\end{array}$ & $\begin{array}{l}\text { New scale based } \\
\text { on Cho et al., } \\
(2002) \text { and } \\
\text { Ranjan and } \\
\text { Bhatnagar } \\
\text { (2011) }\end{array}$ \\
\hline Benchmarking & $\begin{array}{l}\text { - Emphasis on benchmarking } \\
\text { competitors' products and } \\
\text { processes, } \\
\text { - Emphasis on benchmarking non- } \\
\text { competitors' products and } \\
\text { processes } \\
\text { - Effectiveness of benchmarking in } \\
\text { customer service improvement } \\
\text { - Effectiveness of benchmarking in } \\
\text { service cost reduction. }\end{array}$ & $\begin{array}{ll}\text { Adopted from Al- } \\
\text { Mashari } & \text { and } \\
\text { Zairi (2000) } & \end{array}$ \\
\hline $\begin{array}{l}\text { CRM Software } \\
\text { Selection and } \\
\text { integration }\end{array}$ & $\begin{array}{l}\text { - Adequate software selection } \\
\text { - Integration with other software } \\
\text { - Using CRM software to respond to } \\
\text { customer } \\
\text { - Information } \\
\text { infrastructure. }\end{array}$ & $\begin{array}{l}\text { New scale based } \\
\text { on } \quad \text { Krueger } \\
(2000) \quad \text { and } \\
\text { Ranjan } \quad \text { and } \\
\text { Bhatnagar } \\
(2011)\end{array}$ \\
\hline $\begin{array}{l}\text { Customer } \\
\text { Orientation }\end{array}$ & $\begin{array}{l}\text { - Customer satisfaction monitored } \\
\text { regularly } \\
\text { - Extent of customer satisfaction } \\
\text { survey feedback given to managers } \\
\text { - Decrease in complaint } \\
\text { - Extent of the use of customer } \\
\text { feedback to improve product quality } \\
\text { - }\end{array}$ & $\begin{array}{l}\text { New scale based } \\
\text { on Anosike and } \\
\text { Eid (2011) }\end{array}$ \\
\hline Customisation & $\begin{array}{l}\text { - Personalized the transactions } \\
\text { - Personalized quality services in } \\
\text { every customer touch point at any } \\
\text { time } \\
\text { - Using CRM to design and } \\
\text { customize products/services } \\
\text { - Motivate and create a knowledge }\end{array}$ & $\begin{array}{ll}\text { Adopted } & \text { from } \\
\text { Eid (2007) } & \end{array}$ \\
\hline
\end{tabular}




\begin{tabular}{|c|c|c|}
\hline & $\begin{array}{l}\text { orientation and customer centric } \\
\text { culture }\end{array}$ & \\
\hline Training & $\begin{array}{l}\text { - Employees training, } \\
\text { - Availability of resources for } \\
\text { training, } \\
\text { - Frequency of training } \\
\text { - Satisfaction of employees with } \\
\text { overall training } \\
\text { - Number of employees trained in } \\
\text { basic CO concepts }\end{array}$ & $\begin{array}{l}\text { New scale based } \\
\text { on Anosike and } \\
\text { Eid (2011) }\end{array}$ \\
\hline Data Mining & $\begin{array}{l}\text { - Information about the availability } \\
\text { of other product/service that you } \\
\text { market } \\
\text { - Gather customer information } \\
\text { through customer observation } \\
\text { and/or interaction } \\
\text { - Store customer information in } \\
\text { business books and/or files } \\
\text { - Effective management } \\
\text { information and knowledge } \\
\text { - Availability of the customer data to } \\
\text { managers }\end{array}$ & $\begin{array}{l}\text { New scale based } \\
\text { on Winer (2001) } \\
\text { and Ranjan and } \\
\text { Bhatnagar (2011) }\end{array}$ \\
\hline
\end{tabular}

